\title{
O MPA E A EDUCAÇÃO DO FUTURO
}

\author{
Domingos A Giroletti \\ Professor de Teoria das Organizações e de Cultura Organizacional da MPA/FCHPL.
}

Ao sermos convidados os professores de Capital Humano do MPA para participar da Semana de Administração e de Informática organizada pela Faculdade de Ciências Humanas de Pedro Leopoldo, pensamos muito para decidir qual seria a nossa melhor contribuição para o evento. Depois de termos examinado várias hipóteses, decidimos que seria melhor trazer à reflexão da comunidade o documento da UNESCO, intitulado: "Os Quatro Pilares da Educação". Farei uma apresentação geral do documento e alguns comentários. Em seguida, meus colegas farão comentários críticos relacionados ao documento ou considerações específicas, voltadas aos temas dos cursos e das pesquisas que ora realizam.

Por pertencermos à Faculdade de Ciências Humanas de Pedro Leopoldo, algumas questões fundamentais se colocam: Qual será o grande desafio da Educação para o próximo milênio? Como deverá ser a educação no próximo século? Qual o desafio para a nossa Faculdade que, ainda pequena, não deixa de pensar grande e num ato de audácia decide investir, além de novos cursos na graduação, na Pós-graduação e no Mestrado? É oportuno lembrar que a Pós-graduação e o Mestrado vêm para somar e não para diminuir. Ou, usando os conceitos da economia, diremos que eles foram criados para agregar maior valor à faculdade. Em educação diremos que a nova opção veio garantir qualidade e realização às três funções básicas da universidade: Ensino, Pesquisa e Extensão.

O verdadeiro ensino é aquele que tem uma nítida função fecundante: gerar um novo ser pensante, criativo, imaginativo, produtor de conhecimento. Quando falamos que o ensino deverá ser fecundante temos em mente todos métodos de fecundação, do tradicional aos mais modernos inventados pela biotecnologia e pela genética; muito embora no que concerne à nossa espécie não possa furtar-me de declinar que a minha (ou talvez a nossa) preferência continua sendo pelo método tradicional. E as razões são simples. Não haverá espécie humana sem convivência, sem afeto, sem amizade, sem olho no olho, sem paixão e sem amor. Mas não esqueçamos que somos filhos do nosso tempo e que as modernas tecnologias são produtos da inventividade humana e que são necessárias à nossa sobrevivência e ao nosso futuro. Mas a moderna tecnologia não pode substituir o relacionamento nem ser contra a vida, acabando com o meio ambiente de que somos partes umbilicais. Se o ensino é fecundante tem que alimentar a curiosidade, a imaginação e a inventividade. E o uso dos modernos meio é fundamental para possibilitar a criatividade e multiplicar o conhecimento humanos.

A Pós-graduação e o Mestrado na Faculdade de Ciências Humanas de Pedro Leopoldo terão que agregar valor, sobretudo, no campo da pesquisa e da produção acadêmica. Não se concebe mais uma instituição universitária sem pesquisa e sem produção. Aqui reside o grande desafio aos professores que neste ano foram incorporados à Faculdade para viabilizar o Mestrado. Temos que produzir conhecimentos, publicar e formar outros produtores. Hoje a tarde, os nossos alunos do Mestrado estão apresentando os seus trabalhos e projetos de pesquisa à comunidade. Desde já todos estão convidados para participar das sessões dos nossos mestrandos. A partir de fevereiro e março de 2002 estaremos entregando à comunidade e à sociedade brasileira os nossos primeiros mestres em administração. Nossa produção será um item fundamental que ateste a qualidade do nosso 
Programa. Temos também um compromisso que é um desafio para nós professores do Mestrado: mantermo-nos atualizados, produtivos, inventivos. Como iremos reforçar as nossas linhas de pesquisa? Que veículos de comunicação haveremos de criar? Como vamos intensificar o contato e o convívio com nossos alunos para garantir um sistema de orientação eficiente e produtivo? Um cuidado especial com a nossa Biblioteca porque, a despeito da Internet, ela continua insubstituível, dando-nos o suporte que precisamos para as nossas aulas, para mantermo-nos atualizados e para que os nossos alunos possam fazer seus trabalhos e suas teses.

Esta Semana da Administração e da Informática é outro indicador da preocupação extensionista da nossa Faculdade. Ela não pode se esquecer de que é de Pedro Leopoldo. Estar situada aqui não é um mero acidente geográfico. É um compromisso com a Cidade, com a sociedade e com seu povo. A Faculdade tem um compromisso com a qualidade de vida, com o desenvolvimento e com o meio ambiente. Um segundo compromisso é com a micro-região de atuação, a interiorização do desenvolvimento e com a formação de recursos humanos que atuarão em todas as áreas do conhecimento. Não podemos esquecer, em terceiro lugar, que Pedro Leopoldo faz parte da grande região metropolitana de Belo Horizonte e essa vocação gera outros compromissos a estimular a nossa ação e o nosso pensamento.

Mas não termina aqui a responsabilidade da Faculdade de Ciências Humanas de Pedro Leopoldo. Nessa era da globalização ou nesse processo de unificação da humanidade, cresce em todos nós a consciência de que, além de locais e regionais, de sermos mineiros e brasileiros, somos globais. Além das implicações econômicas e sociais que sentimos diariamente na pele diariamente, a globalização, ao provocar uma "compressão espaço-tempo e uma aceleração dos processos globais", quebra a relação tradicional que o homem mantinha com o tempo e com o espaço de tal forma que sentimos que o mundo hoje é menor, as distâncias são mais curtas e os acontecimentos que ocorrem em determinados lugares têm impactos imediatos sobre todas as pessoas em todo o planeta $^{1}$.

A vida humana passou a ser, simultaneamente, local, nacional e global. Este é o privilégio e a responsabilidade de vivermos neste momento histórico. A nossa sobrevivência individual é uma questão local e nacional, mas enquanto espécie é uma questão que se torna cada vez mais universal, global. O nosso ser e a nossa cultura são, ainda, marcados pela nacionalidade e pelo lugar onde nascemos e vivemos e, provavelmente, isto ainda dure para sempre. O homem continua sendo um "ser datado e situado". Por outro lado, cresce a consciência de que fazemos parte, a despeito de nossas diferenças, da mesma humanidade. Temos uma história comum e o nosso destino futuro, a cada dia, torna-se mais interdependente. O nosso lugar continua fixo e nele temos nossas raízes, mas o espaço social em que vivemos não é apenas definido pelo local e, sim, pelas influências das pessoas, das instituições e dos países que vivem distantes de nós. E a tendência futura: o local será cada vez mais formado pelo global ${ }^{2}$.

Tendo esta consciência de sermos simultaneamente locais e globais, regionais e metropolitanos, mineiros, brasileiros e sul-americanos e cidadãos do mundo, aproveitamos o ensejo da apresentação oficial dos professores do Mestrado Profissionalizante de Administração à comunidade universitária - aos alunos, aos nossos colegas professores e aos funcionários - e à sociedade de Pedro Leopoldo aqui presentes, para trazer à reflexão um documento - Os Quatro Pilares da Educação - elaborado

\footnotetext{
${ }^{1}$ Hall, S. A identidade Cultural na Pós-modernidade; tradução Tomaz Tadeu da Silva e Guaracira Lopes Louro - $4{ }^{\mathrm{a}}$ Ed.Rio de Janeiro, DP\&A, 2000, p.69.

${ }^{2}$ Idem, ibidem, p. 72/73.
} 
pela UNESCO em 1998. ${ }^{3}$ Esse documento traduz o nosso compromisso com a comunidade acadêmica, com Pedro Leopoldo, com o país e com a humanidade. Creio que ele se preste a expressar também a filosofia de trabalho que vem sendo desenvolvido pela Fundação Cultural Dr. Pedro Leopoldo desde sua fundação e, certamente, constituir-se-á em seu programa de educação para o futuro.

O referido documento é singelo e de compreensão fácil, mas de uma grande profundidade e uma oportuna visão de futuro. É um documento escrito para os homens e as mulheres de hoje, pensando a educação para o presente e projetando-a para o próximo milênio. Sendo elaborado pela UNESCO é superior aos interesses mais imediatos, às correntes políticas e aos sistemas geopolíticos mundiais em disputas hegemônicas entre si. Apesar disto, não deixa de ter os pés na terra e possibilita que pensemos a educação do homem da nossa aldeia, região, país ou como cidadãos deste mundo globalizado.

Como os futuros cidadãos do nosso mundo e de nossa aldeia deverão ser educados?

A resposta é clara. O documento rejeita uma visão meramente instrumental e produtivista da educação, exclusivamente voltada para o trabalho ou para o mercado. Reconhece que grande parte do ensino formal ainda se limita quase que exclusivamente à transmissão de conhecimentos ou à aprendizagem de uma profissão, que perdem validade em pouco tempo dado o ritmo frenético das mudanças. Diante disto, perguntava: como deverá ser a educação do cidadão do século XXI e do próximo milênio? A educação do homem do presente e do futuro deverá ser organizada, segundo a UNESCO, em torno de quatro aprendizagens fundamentais: "o" aprender a conhecer", o "aprender a fazer", o "aprender a viver juntos ou conviver com os outros" e o "aprender a ser", via essencial que integra a três precedentes".

Pelo primeiro pilar - "aprender a conhecer" - o documento da UNESCO (2000, p.90/3) dá ênfase ao domínio dos próprios instrumentos do conhecimento como "meio e finalidade da própria vida humana". É "meio" porque o conhecimento na nossa época se tornou o principal fator produtivo e um dos principais requisitos para a nossa sobrevivência particular e enquanto espécie. É "finalidade" porque o conhecimento pode ser considerado como um dos fundamentos da vida humana e porque o compreender, o conhecer e o descobrir tornam-se fonte inesgotáveis de prazer e de auto-realização.

Além do mais o documento nos adverte contra a pretensão (e não raras vezes contra a ansiedade) da onisciência e do tudo conhecer, instigados pela Internet que, virtualmente, permite o acesso às principais bibliotecas e à maior parte das obras publicadas no planeta. Ele faz, ainda, uma advertência contra a especialização excessiva e recomenda que o conhecimento transmitido seja ministrado juntamente com a cultura geral. Esta não deve ser confundida com "generalidade" que, segundo Ítalo Calvino, "é pior praga da escrita de hoje". ${ }^{4}$ Parafraseando o autor ítalo cubano, diremos que a generalidade é o pior produto que um sistema educacional possa vir a produzir.

\footnotetext{
${ }^{3}$ Educação: um Tesouro a Descobrir, $4^{\mathrm{a}}$.ed. São Paulo, Cortez; Brasília, MEC/UNESCO, 2000 (cap.4). De ora em diante será citado como UNESO, 2000.

${ }^{4}$ Calvino, I. Seis Propostas para o Próximo Milênio; tradução Ivo Barroso, São Paulo, Companhia das Letras, 1990, p. 137.
} 
O documento da UNESCO reafirma acertadamente a importância da formação cultural que, além de ser cimento das sociedades no tempo e no espaço, favorece a abertura do ser humano para outros campos do conhecimento, permitindo uma visão interdisciplinar e o estabelecimento de uma maior sinergia entre as mais diversas disciplinas. E, provoca afirmando que: o sucesso de um programa de educação (aí incluído o primário), poderá ser medido pela sua capacidade de transmitir às pessoas o impulso e as bases para o aprender permanente ou para o aprender a aprender que deverá ser mantido de forma continuada ao longo da vida.

O segundo pilar, o "aprender a fazer", refere-se à formação profissional (UNESCO, 2000, p.93/6). Nesta nossa era chamada de terceira revolução industrial, a formação profissional passa por profundas mutações em função das mudanças na tecnologia, nos processos produtivos e no mercado. Não há mais profissão ou conhecimentos que se aprendem na Escola para serem usados pelo resto da vida. Da mesma forma, as tarefas manuais e físicas de produção são gradativamente substituídas por outras mais intelectuais que dizem respeito ao comando, à manutenção ou à vigilância de máquinas ou processos; ou ainda aquelas são substituídas por tarefas de processos ou de estudo de organização na medida em que as próprias máquinas se tornam mais inteligentes e o trabalho se "desmaterializa".

Por isto, ao caracterizar a formação profissional na atualidade, o documento dá ênfase à "competência individual", um coquetel que mistura, em proporções variadas, a formação técnica atualizada com capacidade de iniciativa e de comunicação, com aptidão para o trabalho em equipe, com gosto pelo risco e com habilidade para gerir e resolver conflitos. Ítalo Calvino, ao defender a "leveza" em oposição ao "peso do viver" como primeira qualidade da literatura do próximo milênio parece coincidir com este diagnóstico e usa a ciência da nossa época como alimento para fundamentar a sua proposição; assim, cada ramo da ciência, escreve, parece querer demonstrar que o mundo repousa sobre entidades sutilíssimas como o DNA, os impulsos neurônicos, os quarks, os neutrinos; na informática, a leveza do software comanda e age sobre o hardware e as outras máquinas; da mesma forma, a segunda revolução industrial é marcada pela leveza dos fluxos de informação comandados pelos bits bem diferente das grandes fábricas e da maquinaria pesada dos primórdios da era industrial". ${ }^{5}$ Não só a literatura do próximo milênio mas o processo educativo deverá ser comandado por esta "leveza", traço característico do sistema produtivo atual baseado na inteligência e no conhecimento.

O terceiro pilar é o "aprender a viver juntos ou conviver com os outros" (UNESCO, 2000, p.96/9). O globalização, ao acentuar a "tendência em direção à homogeneização global e à fascinação com a diferença", tanto aproxima os diferentes quanto, pela acentuação das desigualdades sociais, regionais e entre países, pode acelerar a separação e os conflitos interétnicos no mesmo território ou entre estados vizinhos. A diminuição da violência e a busca da paz tornam-se objetivos cada vez mais permanentes. Não há dúvida de que a experiência da convivialidade multirracial e multicultural praticada no Brasil desde a colonização, pode e deverá ser uma referência cada vez mais importante para o mundo de agora e do futuro. O "aprender a viver juntos" deverá traduzir-se em maior capacidade de compreender o diferente, argumentar, dialogar, negociar e participar de projetos comuns. A prática de esportes e os programas de natureza cultural oferecem infindas possibilidades para um convívio mais fraterno e enriquecedor entre pessoas diferentes, mas que podem, pacificamente, perseguir um objetivo comum.

\footnotetext{
${ }^{5}$ Idem, ibidem, p.20.

${ }^{6}$ Hall, S. op. cit. p. 77.
} 
Pelo último pilar, o "aprender a ser", o documento da UNESCO (2000, p.99/101) preconiza o compromisso da educação com o desenvolvimento total da pessoa humana: espírito e corpo; inteligência, sensibilidade e sentido estético; vontade, responsabilidade individual e espiritualidade. O "aprender a ser" implica o auto-conhecimento, a afirmação da autonomia do sujeito e seu espírito de iniciativa e de independência; reafirma o reconhecimento do outro: a diversidade de personalidades e a pluralidade de estilos, valores e idéias que fazem a riqueza do ser humano e a beleza da humanidade.

Neste aspecto, não posso furtar-me de fazer uma última analogia com Ítalo Calvino quando afirma que a quinta qualidade da literatura do próximo milênio deverá ser a "multiplicidade" em oposição à "unicidade". Há, novamente, uma outra coincidência de diagnóstico e de propósitos entre a visão do autor ítalo-cubano sobre a literatura e do documento da UNESCO com relação à educação. Um sistema educacional, que objetiva preparar o sujeito para o mundo de incerteza e para a construção do futuro deverá dar maior ênfase à curiosidade, à criatividade, à inovação e à imaginação; da mesma forma a "multiplicidade" da literatura se expressa por ser um método de conhecimento que tem a ciência como inspiração, por estabelecer uma rede de conexões entre fatos, entre pessoas e coisas deste mundo; e nessa tarefa o conhecimento, a imaginação e a inventividade predominam. Por que a coincidência nesta ênfase? A primeira vista poderíamos dizer que ela adviria da matéria humana que melhor se expressa no interrogar-se de Ítalo Calvino: "quem somos nós senão uma combinatória de experiências e informações, de leituras e de imaginação?"7. Certamente, esta inventividade humana será o leitmotiv a inspirar, além da literatura, a educação durante o presente século e milênio. Inventividade, é preciso que se lembre, comprometida com a viabilização do desenvolvimento dos povos e países e com a continuidade da espécie humana.

Finalmente, uma palavra de alento aos educadores e aos produtores do conhecimento. A despeito das reviravoltas que ocorrem, de um lado, no mercado, nas tecnologias, na produção e no comércio internacional e, de outro, no mundo do trabalho, nos conhecimentos e nas novas modalidades de ensino, reafirmamos a nossa confiança na educação e na nossa profissão de professores e de educadores. Nem, talvez, seja temerário prever que, no futuro, o conhecimento e a educação serão cada vez mais demandados e os educadores e os produtores de conhecimento cada vez mais necessários; nesse reconhecimento reside o acerto da Fundação Cultura Pedro Leopoldo em investir, além dos novos curros de Graduação, na Pós-graduação e no Mestrado. O futuro da humanidade dependerá cada vez mais do conhecimento e da inventividade humana que o produz, o engendra e, cada vez mais, o refaz num processo contínuo e ininterrupto.

\footnotetext{
${ }^{7}$ Calvino, I. op. cit. p. 121 e 138.
} 